Athens Journal of Sciences- Volume 8, Issue 4, December 2021 - Pages 249-272

\title{
Mineral Exploration in Mawat Region, Kurdistan-Iraq, Based on Satellite Data and Terrain Prospection
}

\author{
By Marinko Oluic ć, Sreten Romandic ${ }^{ \pm} \&$ Ratko Vasiljević
}

The main goal of the presented exploration was to estimate potential for mineralization in the Mawat ophiolitic massif in Kurdistan, Iraq. The aim of the study was to explore existing copper mineralization and assessor elements gold, platinoids and chromium. Geological exploration detected two types of $\mathrm{Cu}$ occurrence a) secondary $\mathrm{Cu}$ carbonates (malachite) and b) $\mathrm{Cu}$ sulfides (chalcopyrite-pyrite). The Mawat region is mostly built of ultrabasic and basic rocks: peridotites, gabbros, serpentinites and basalts which are heavily deformed, with faults mostly oriented NNW-SSE, and NE-SW. The first phase of exploration comprised digital processing of ASTER and QuickBird satellite images, with appropriate geometrical and radiometric corrections and transformation into coordinate system. Color composite images were produced in different scales. They served to define lithological composition, tectonic settings, location of the points of interest etc. The field work was designed to check satellite data in situ, with focus on perspective rock formations, which might host copper mineralization, and other elements. The host rocks of the ore occurrences are primarily gabbros and metagabbros intersected by diabase dykes, epidote and quartz veins. Secondary mineralization is the product of surficial weathering and it is represented by malachite and limonite. The geophysical survey was very useful in the detection of area with elevated induced polarization and low resistivity. Three perspective areas have been selected for detailed explorations: Waraz, Mirava-Chenara and Konjirin-Kuradawi. The concentration of copper varies highly in very wide ranges; the maximum measured concentration of $\mathrm{Cu}$ was determined in Waraz area 6.7\%. Some rock samples also show concentration of gold from 0.36 to $2.59 \mathrm{ppm} \mathrm{Au}$.

Keywords: Mawat ophiolitic massif, geologic-geophysical explorations, copper mineralization, Kurdistan-Iraq

\section{Introduction}

The goal of this exploration was to estimate potential for mineralization of Mawat ophiolitic massif in Kurdistan, Iraq. The aim of the study was to explore existing mineralization of copper as well as of other metals like gold, platinoids, chromium etc. The explored area has about $250 \mathrm{~km}^{2}$, about $40 \mathrm{~km}^{2}$ of which was selected for detailed exploration of mineral resources. In addition to geologicgeophysical survey, satellite ASTER and QuickBird imagery have also been used. Color composite images were produced in different scales, which served for rock

*Prof. Dr., GEO-SAT Ltd, Croatia.

${ }^{ \pm}$Mr.sc. Researcher, GEO-SAT Ltd, Croatia.

Dr. Researcher, ECOINA Ltd, Croatia. 
discrimination, registration of tectonic elements, location of control and sampling points, etc. The field work was designed to check satellite data in situ, with focus on perspective rock formations, which might host mineralized rocks. The ore host rocks are primarily gabbros and metagabbro intersected by diabase dykes and epidote and quartz vein.

Secondary mineralization is the product of surficial weathering and is represented by malachite and limonite. The geophysical explorations were applied in detection of anomaly area (inducted polarization- $I P$, magnetic resistivity and $S P$ methods) and proved very useful.

Three areas: Waraz, Konjirin-Kuradawi and Mirava-Chenara area were selected as potential by perspective for increased mineralization and were subjected to detailed exploration and sampling for chemical and petrological analyses. Measurement $\mathrm{Cu}$ in rock samples in ppm are as follows: Waraz area 1.53-60,705 ppm, Konjirin-Kuradavi 68-36287 ppm and Mirava-Chenaran 135-16,803 ppm. Maximum value of $6.7 \% \mathrm{Cu}$ was determined in Waraz area. In some rock samples the gold concentration of 0.36 and $2.59 \mathrm{ppm}$ were registered.

\section{Study Area}

The study area is situated in northeastern part of Iraq (Kurdistan), about 30 $\mathrm{km}$ north of Sulaimany City (Figure 1), with topography altitudes which range from ca $940 \mathrm{~m}$ (south part) to more than $1,400 \mathrm{~m}$ a.s.l. (north part). The main ultramafic body represents low area, surrounded by high peaks made of mafic intrusions which are grey and dark green in color showing pseudo stratification.

Figure 1. Positional of the Explored Area in Mawat Region, Kurdistan-Iraq

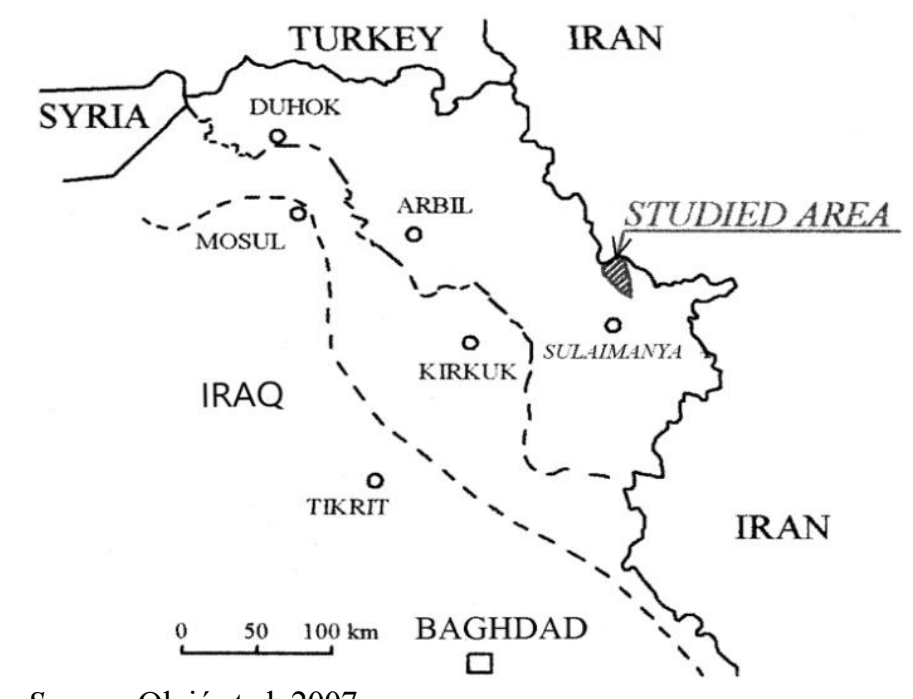

Source: Oluić et al. 2007. 


\section{Geological Setting}

According to previous geological studies, the studied area belongs to the Zagros Mt. chain which extends SE-NW. It is a young Alpine orogeny formed by collision of African elements with Eurasian continental plate, and closing the Tethyan Ocean (Ismail et al. 2017). The Zagros orogenic system consists of several large distinctive geotectonic units which correspond to Cretaceous-Palaegene subduction of the Arabian plate beneath the Central/East Iran microplate, which is still active in the prolongation within the Gulf area. A wider area is built of Arabian platform formations, covered by Tertiary foreland units. Early foreland formations are Kolosh Tanjero, Shiranish, and late foreland formations are Sinjar, Gercus, Pila Spi, Lower Fars and Upper Fars (Hassan et al. 2015). These molasse formations are overthrust by ophiolitic mélange incorporated within the Qulqula Uper Cretaceus hinterland group. They indicate a regional Zagros nappe system and have a tongue-shaped form, named Mawat Nappe. Its central part consists of ophiolite and metamorphic rocks, surrounded by outcrops of Red bed series, as well as Naopurdan Series. Al-Mehaidi published Simplied geological map of Mawat Ophiolite Complex NE Iraq (Al-Mehaidi 1974).

More detailed chronological overview of earlier studies is given in the following section.

\section{Previous Studies}

Mawat ophiolitic massif was studied by numerous geologists. Bolton (1955) made the first geological map of this region and discussed tectonical zones as well as economic prospects of the area, and named, and distinguished both Bulfat and Quandil thrust blocks.

Geology of the central sector of the Mawat igneous rocks has been published by Jassim (1975). The dispersion of $\mathrm{Cu}, \mathrm{Ni}$, and $\mathrm{Cr}$ mineralization in Mawat ophiolite complex was reported by Al-Hashimi and Al-Mehaidi (1975). The northern part of studied area was explored by Hamasalh (1982) who wrote that ultramafic rocks comprise peridotites, dunites, pyroxenites and hornblendites which contain more than $90 \%$ mafic minerals.

Zagros Upper Cretaceous ophiolites as well as similar-aged ophiolites in Turkey, Cyprus and Oman are coeval and represent remnants of a late Cretaceous oceanic fore-arc formed along the southern margin of Eurasia. Zagros ophiolites and other Upper Cretaceous Tethyan ophiolites of SW Asia are broadly similar in terms of age, lithological components and geochemical evolution (Moghadam and Stern 2011).

The Mawat extensional basin formed without creation of new oceanic basement. During the extension, huge volumes of mafic lava were intruded into 3 block during the Late Cretaceous. The Mawat complex does not show a typical ophiolite sequence, and it is composed mainly of mafic rocks, which have been intruded into an extensional tectonic regime on the Arabian passive margin. It is possible that some extensional regime affected the passive margin of the Arabian Plate since the Late Paleozoic to the Late Mesozoic and caused thinning of the 
lithosphere and hot depleted mantle-plume material was melted to a high degree (Azizi et al. 2013).

The geological prospecting for copper mineralization in Waraz locality, Mawat Igneous complex was performed by group of domestic experts such as AlHilali et al. (1991), etc. According to earlier conclusions, Mawat massif was generally considered without economical importance (Bolton 1955). Power (1954) considered copper occurrences unimportant and without economical potential. Smirnov and Nelidov (1962) in Waraz area determined $3.71 \%$ of $\mathrm{Cu}$ and concluded that mineralization is insignificiants with no commercial concentrations of copper. However, some newer exploration (Al-Hashimi and Al-Mehaidi 1975) reported that copper content which in the mineralized zone reaches up to 54140 ppm $\mathrm{Cu}(5.4 \% \mathrm{Cu})$. Detailed geological investigations in the Waraz locality with the one borehole ( $240 \mathrm{~m}$ deep) allows for recognition of two types of $\mathrm{Cu}$ occurrence a) secondary $\mathrm{Cu}$ carbonates (malachite) and b) $\mathrm{Cu}$ sulfides (chalcopyrite-pyrite) which is probably primary mineralization. Geochemical analysis of borehole samples provided concentrations of copper in span from $11 \mathrm{ppm}$ to $4,910 \mathrm{ppm}$ (average $638 \mathrm{ppm}$ ).

As it is prominent from older references, mineral ore potential in this area have been known for a long time, but, remains unexplored due logistical and sometimes political reasons, and due the same reasons, these areas are difficult to map using traditional methods (Othman and Gloaguen 2014). The authors demonstrated the potential of the Support Vector Machine (SVM) algorithm for classifying the lithological units of Mawat ophiolite complex, using Advanced Space-borne Thermal Emission and Reflection radiometer (ASTER) satellite data. The SVM algorithm was specifically used to detect chromite occurrences. The collected samples from fieldwork show corresponded to remote sensing, which has important implications for starting to explore chromite in the ophiolite regions in Iraq using remote sensing tools (Othman and Gloaguen 2014).

Prospectivity of this area was confirmed with more recent papers: Yara and Mohammad (2018) concluded that "Two types of primary mineralization occur in the Mirawa, sulfides which are represent by pyrite and chalcopyrite. The oxides are magnetite and ilmenite. They occur either as aggregates or disseminated and as vein fillings. Two stages of mineralization have been identified according to textural features (synentic and epigenetic). The alteration of this primary phase by supergene solutions forms secondary mineralizations which are represented by covellite, hematite and goethite. Detailed petrographic and microstructure observations reveal that formation of the Mirawa mineralization was related to magmatism and shearing as a result of Eocene crustal extension during the final stages of exhumation of a metamorphic rock complex".

Recent exploration of Mawat Ophiolite complex documented copper sulfides (chalcopyrite, bornite, chalcocite and covellite) in copper-rich deposits (Yassin et al. 2015).

Yara (2019a) summarised knowledge on copper deposits in Mawat region and pointed that copper mineralization underwent different stages of deformation and alteration and distinguished two types of primary mineralization: (1) sulfides, which are represented by pyrite and chalcopyrite, and (2) oxides, represented by 
magnetite and ilmenite. The mineralization occurs as disseminated and vein filling. The mineral assemblage is chalcopyrite, pyrite, magnetite and ilmenite as primary minerals, whereas covellite, malachite, hematite and goethite are the secondary minerals.

Yara (2019b) confirmed that $\mathrm{Cu}$-mineralization consists of chalcopyrite, pyrite, malachite and azurite, with $\mathrm{Cu}$ content between 2.84 and 23\%. According to mineral paragenesis in the Kuradawe copper occurrence, using petrographic, geochemical and stable isotopes methods, he concluded that the ore minerals and the host rocks suffered the same metamorphic history. Paragenetic sequence show three stages of mineralization; orthomagmatic, hypogene and supergene. The $\delta 34 \mathrm{~S}$ data of the sulfide minerals reveal that the source of the mineralized fluids is of granitic composition.

It is important to point that Al-Bassam (2013) referenced to lack of estimation of economic properties of these deposits: Despite the numerous showings of copper mineralization in the Kurdistan Region of NE Iraq, none of which have been investigated in detail to enable accurate assessment of tonnage, grade, mining conditions and upgrading potential. However, in view of the numerous $\mathrm{Cu}$ deposits in Cyprus, Turkey, Iran and Oman, which are all related to the Cretaceous ophiolites and are commercially producing copper, it can be anticipated that the potential of discovering commercial $\mathrm{Cu}$ deposits in the age-equivalent ophiolite complexes of the Kurdistan Region is encouraging.

\section{Geologic-Tectonically Exploration}

\section{Satellite Imagery - Analysis and Interpretation}

In this study, Satellite imagery obtained by Tera-ASTER and QuickBird satellites were used in two exploration phases (Oluić et al. 2007; 2008). ASTER image cover wide spectral region with 14 bands and spatial resolution which varies from $15 \mathrm{~m}, 30 \mathrm{~m}$ and $90 \mathrm{~m}$, covers the area of $60 \times 60 \mathrm{~km}$. These resolutions were suitable for regional interpretation of the Mawat complex. The images were used to evaluate large areas of terrain for a variety of properties like tectonics, rock discrimination, and geomorphology. QuickBird imagery has higher resolution (1-4 m) and was useful for more detailed analysis of physical landforms such as outcrops or structural features and for location of control and sampling points etc.

ASTER satellite color composite was produced from different spectral channels: $6,3,1 ; \mathbf{3}, \mathbf{2}, \mathbf{1} ; \mathbf{9}, 7,5$ and 3N/3B, in scale 1:25,000, while QuickBird Color composite produced in the scales $1: 10,000$ and 1:1,000. Color composites in the cartographic projection, were used for orientation, basis for drawing of collected data (GPS), and for tectonic interpretation and rock discrimination (Figure 2). 
Figure 2. ASTER Colour Composite (VNIR \& SWIR) of Mawat Ophiolitic Complex: B-Basalt, Diabase, Metadiabase; G-Gabbro, N-Wallash-Naopurdan Nappe, Metagabbro; $\boldsymbol{P}$ - Peridotite, Serpentite, $\boldsymbol{R B}$ - Mollase - Redbed Series, FFold Zone; $Q$ - Qulgula

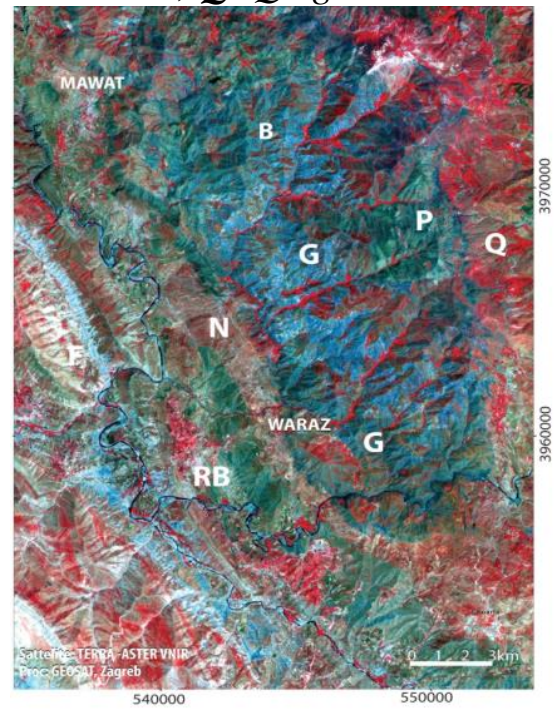

Source: image was recorded in 2003, digital proc. Oluić 2007.

In the NE part of the explored area predominant rocks are basalt and diabases (B), meta gabbro and gabbro $(\mathrm{G})$, peridotites and serpentites $(\mathrm{P})$, and the zone of Mollase-Redbeds unit (RB). In the SW part Mollase-Redbed series dominates, which extends in zonal form around the central part of the terrain. Wallash and Naopurdan Nappe have been thrusted ower Redbed series, which are very intensively disturbed (folded), with many plicative structures (anticlines and synclines). The rocks are intensely ruptured, with numerous faults predominantly NW-SE orientation (Oluić et al. 2008) (Figures 3-5).

Figure 3. Digital Terrain Model of Mawat-Waraz Area (Satellite ASTER Image Shaded Relief Azimutt $=315^{\circ}$ )

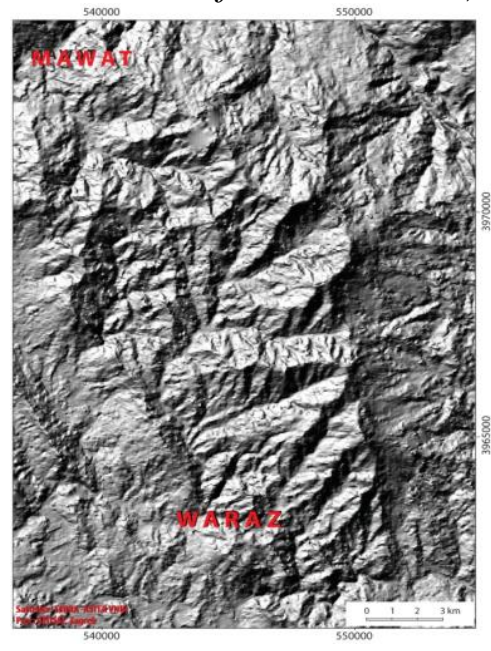


Figure 4. Linaements in Mawat-Waraz Area Registrered on ASTER Imagery

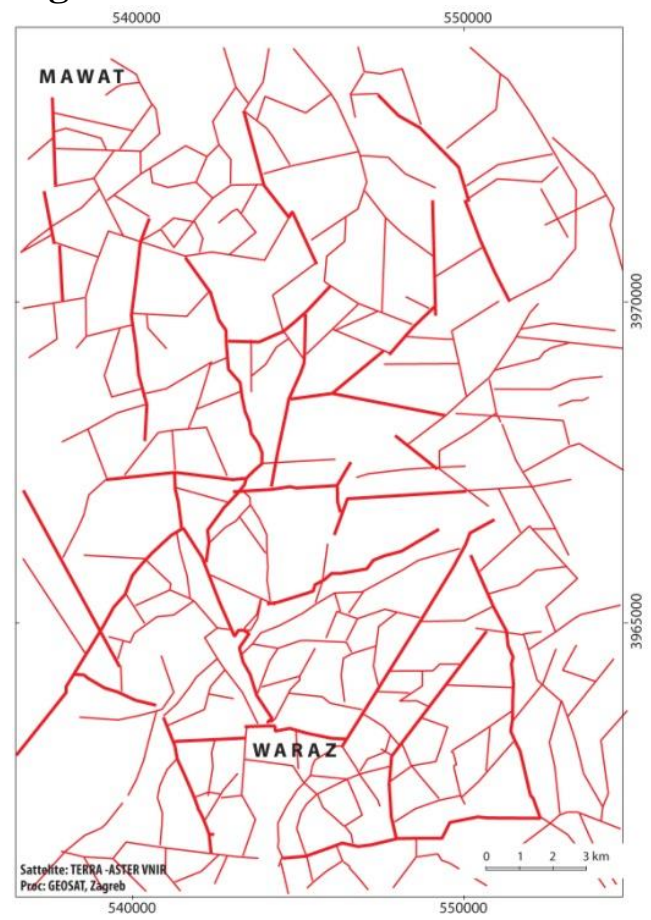

Figure 5. Rose Diagram of Lineaments in Mawat-Waraz Area

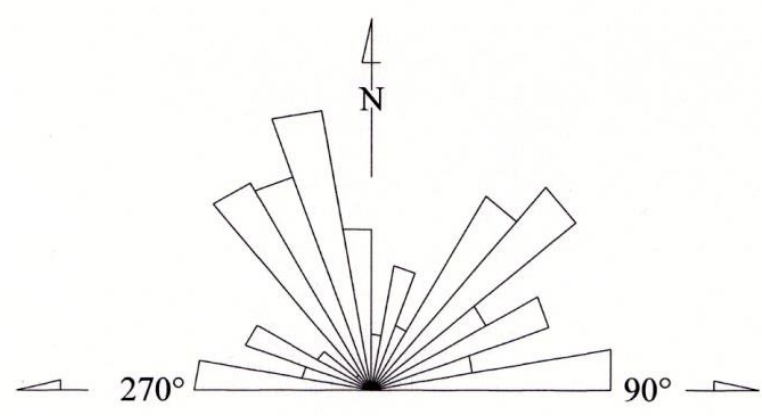

Dominant strikes of faults are NNW-SSE and NE-SW. Streams and deep valleys are predisposed by faults and are located along them (direction NE-SW). The localities on intersections of different fault systems frequently show enrichment in copper mineralization.

\section{Field Work}

The field work comprised two phases; first, gathering general information on geology of the explored area, and the second focused on detailed observation on the ore occurrences, their host rocks, mineralization, etc. The field work comprised cruises crosscutting geological units of the Mawat ophiolitic complex to acquire general idea on their mutual relationship with special accent on the position of mineralization. The rock composition is very heterogeneous, and the area is heavily tectonized (Figures 6 and 7). On crosscuts we have observed characteristics of 
upper Cretaceous Shiranish, Tanjiro, and Agra formations, Redbed series (molasses unit), and Naopurdan-Wallash Formation (melange nappe).

Figure 6. Redbed Sediments - Intensely Folded, in Front of Zagros Overthrust

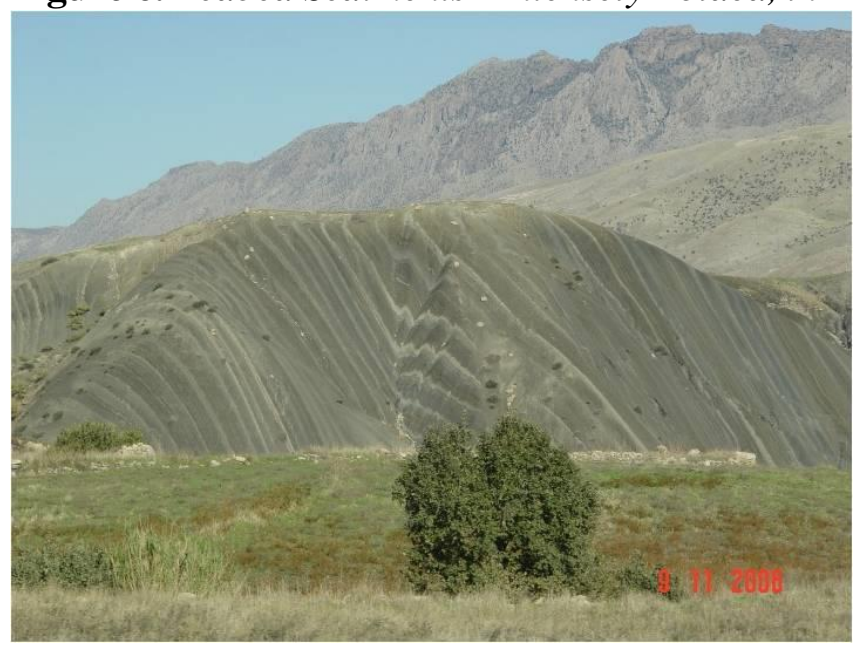

Figure 7. Bulfat Rock Complex in Forehead of Zagros Owerthrust

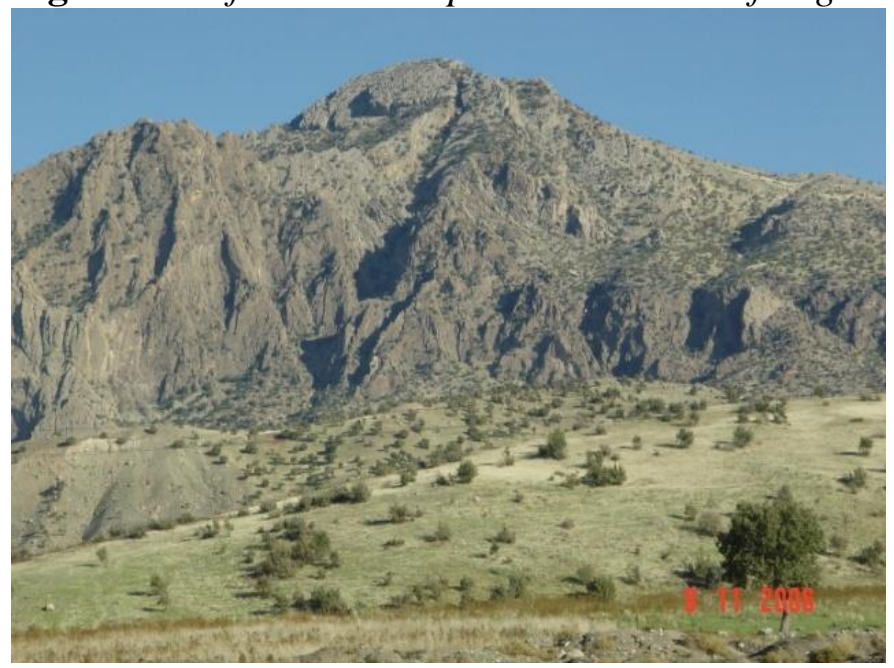

Special attention was given to the Mawat nappe ophiolite rocks including peridotites, serpentinites, gabbros, basaltic rocks and metamorphics rocks of the Gimo sequence. More detailed work was carried out on the three separate areas which were recognized as most promising for copper mineralization.

Detailed Exploration of the Separated Locality

Three localities were identified as potential perspective zones of increased sulfide mineralization, and selected for detailed geological and geophysical explorations. These are Waraz (A), Kanjirin-Kuradawi (B) and Mirawa-Chenara (C) localities (Figure 8). 
Figure 8. ASTER Color Composite of Waraz-Mawat Area and Perspective Localities $(A, B, C)$

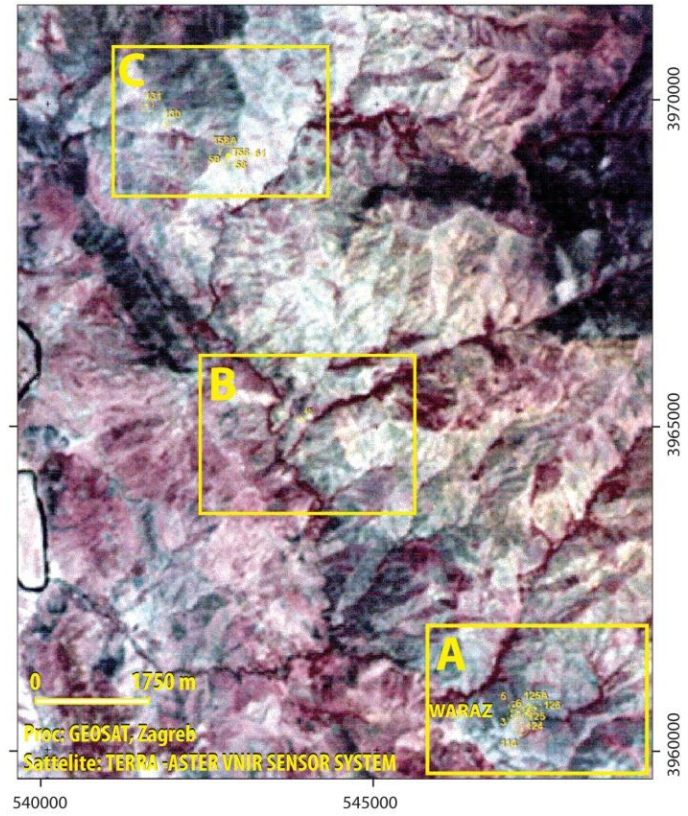

\section{Waraz Area (A)}

Waraz area is located in southern part of Mawat ophiolitic massif and has the surface of about $12 \mathrm{~km}^{2}$ (Figure 8). Based on interpretation of satellite data, geological field reconnaissance and geophysical survey, as well as microscopic and geochemical study, the Geological sketch-map was produced displaying the host rocks, tectonic elements and mineralization zone (Figure 9).

Figure 9. Geological Sketch-Map of the Waraz Area with Mineralization Zone

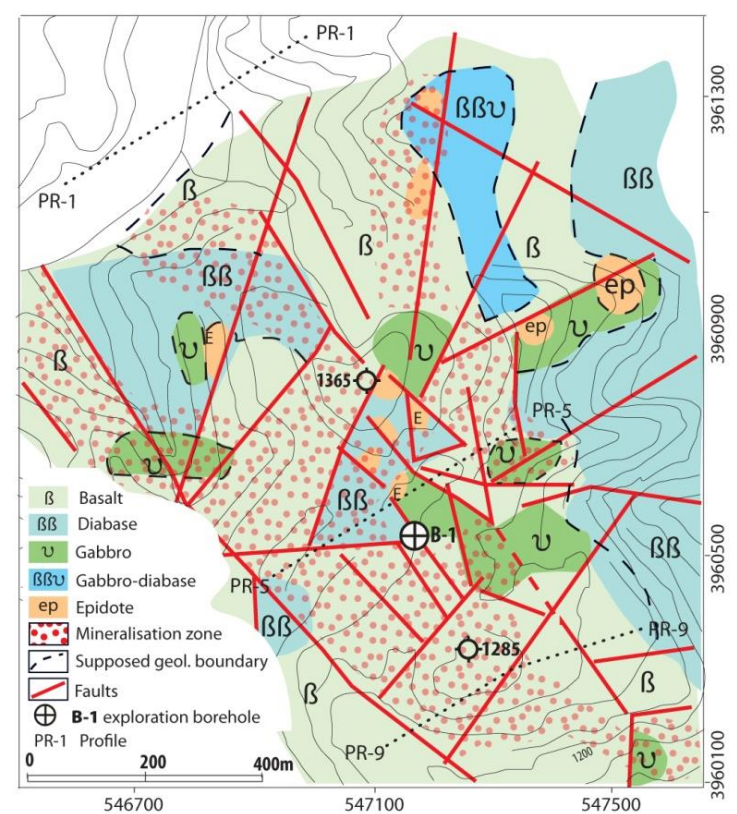

Source: Oluić et al. 2008. 
The map illustrates distribution of major rock types (upper pillow lavas, sheeted dykes etc.), and perspective zones of copper mineralization. More dominant rocks are basalts $(\beta)$ and diabase $(\beta \beta)$, followed by gabbros $(U)$ which are frequently followed by epidotes veins, isolated in different blocks. The terrain is intensely tectonized and cut by numerous faults in various orientations (Figure 10).

Figure 10. Rose Diagram of Ruptures in Waraz Area

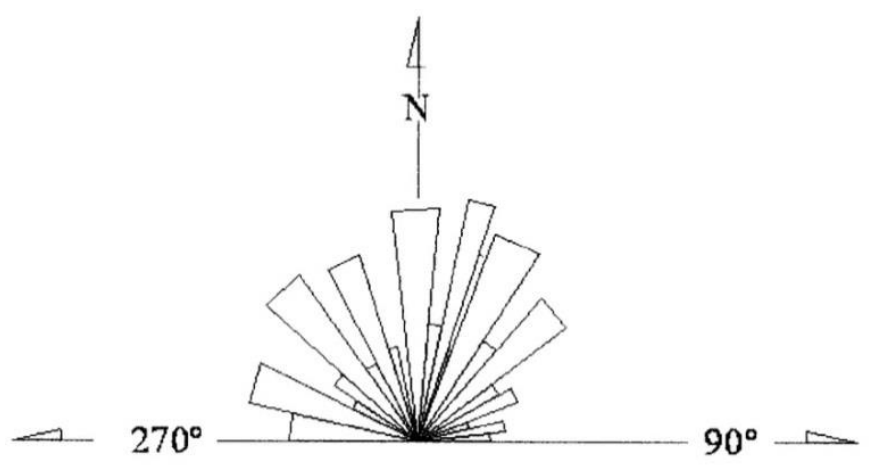

The mineralization zone extends coherently in SE-NW direction in the length of about $1,500 \mathrm{~m}$ and about $800 \mathrm{~m}$ wide in the central part of explored terrain. Mineralization is mostly located in pillow lavas, basaltic dykes and gabbro-diabase formation (Figure 11).

Figure 11. Pillow Lava Higly Tectonized Contains Copper Mineralization

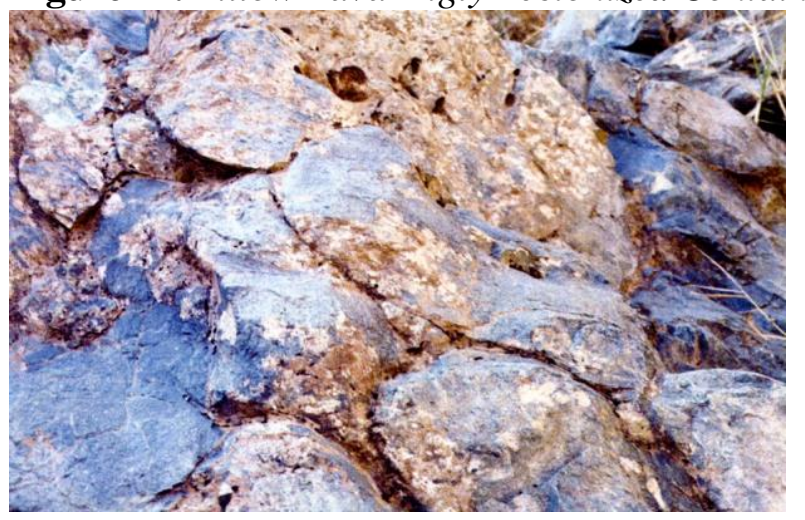

Copper ore crops out as thin horizons, ranging from $10 \mathrm{~cm}$ to $50 \mathrm{~cm}$ in thickness and between 1 to $5 \mathrm{~m}$ in length, distributed within an area of about 0.4 $\mathrm{km}^{2}$. Mineralization is situated within sheared and fractured zones in the basalts and greenschists, closely associated with acidic rocks and quartz veins. The sheared and fractured zone strikes NW and dips $50-70^{\circ}$ to NE. Mineral association consists of malachite, pyrite, limonite and chalcopyrite. The copper content in mineralized zone varies in very wide ranges from 1.53 to $60,505 \mathrm{ppm}$.

Primary minerals in the mineralization zone are represented by: chalcopyrite, bournite and pyrite. In the oxidation process from chalcopyrite, malachite and limonite were developed, and from pyrite formed limonite. The rocks were 
intensely fractured and dissected by numerous epidotic veins. Mineralization is evidenced by limonatization which primarily follows epidotic veins. At places, one may find traces of the secondary copper mineral malachite, originated by weathering of chalcopyrite. The gabbro-diabase formation is crosscut by numerous epidote and, in lesser extent, quartz veins. The intensity of mineralization correlates well with the intensity of epidotisation.

Geophysical survey

Geophysical survey (geoelectric and geomagnetic techniques) were utilized with the aim to identify a) the distribution of lithological units with sulfide mineralization, $b$ ) faults and fault zones, and c) the intensity of total magnetic field $(\Delta T)$. Geoelectric mapping and sounding was applied for the geophysical/ geoelectric surveys, which included induced polarization (IP) techniques electrical resistivity method. The used method in combination with field reconnaissance resulted in data showing sulfide mineralization and its field distribution (Figure 12).

Figure 12. Induced Polarization (IP) Anomaly and ga Value of Lower and Higher Resistivity (B-1 Borehole)

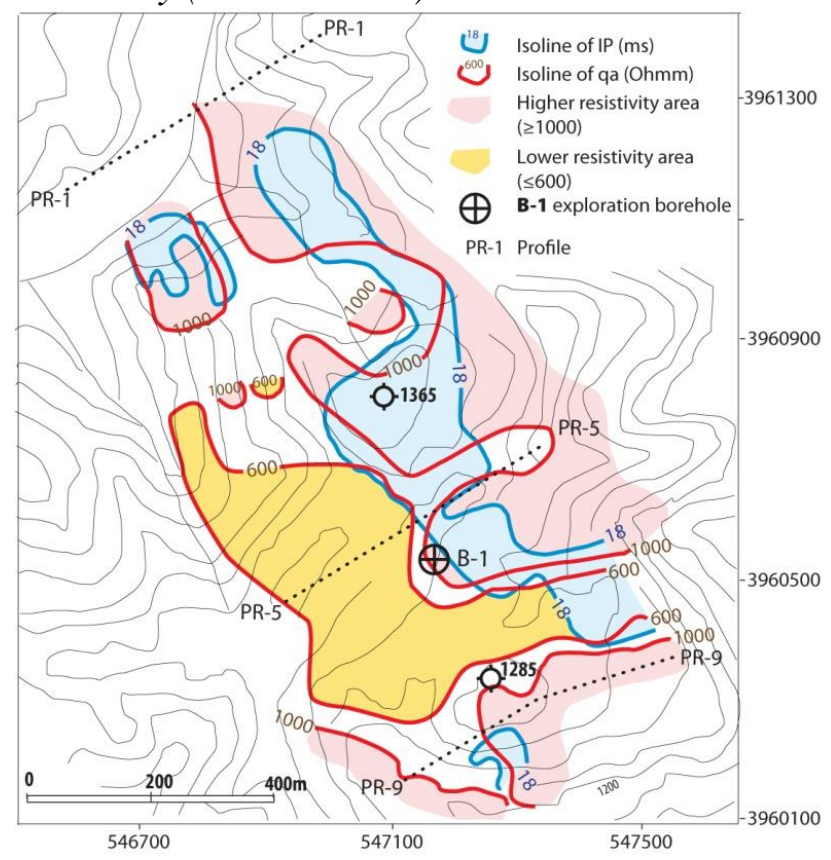

The zones with increased induced polarization- $I P$ value are, as a rule, the zones of increased sulfide mineralization, which were registerd almost in all measured profiles, in the area of about $1.5 \mathrm{~km}^{2}$. The $I P$ values showed that the primary sulfides are situated in the compact gabbro-diabase rocks. Larger zones of lower electrical resistence, characteristic for diabase rocks with enrichment of secondary minerals (limonite, malachite with epidots), are located westwards and eastward of the exploration borehole B-1.

The higher $I P$ values were registared in the areas with increased mineralization of secundare minerals (limonite and malachite with epidots). The values of 
gradients self- potentia $(S P)$ changed from $-25 \mathrm{mV}$ to more than $+45 \mathrm{mV}$. This data suggest that the increased self-potential $I P$ are related to the areas with increased values of IP polarization. Decreasing values of $I P$ indicate secondary mineralization like in the locality west of borehole B-1. There are registered lower values of eletric resistivity because of increased mineralization.

The anomalies of $\Delta T$ changed within bounds from 46,700 to 48,600 that indicate strong magnetic field, because of the presence of basalt and metabasalt with magnetic minerals (e.g., piroxene). The expressive anomalies of $\Delta T$ compared with anomalies of $I P$ are shown in Figure 13. It is obvious that the orientation of anomaly have NW-SE strike that coincides with tectonic dislocations.

Figure 13. Waraz Locality: IP Anomaly and Intensity of Total Magnetic Field $\boldsymbol{\Delta T}$

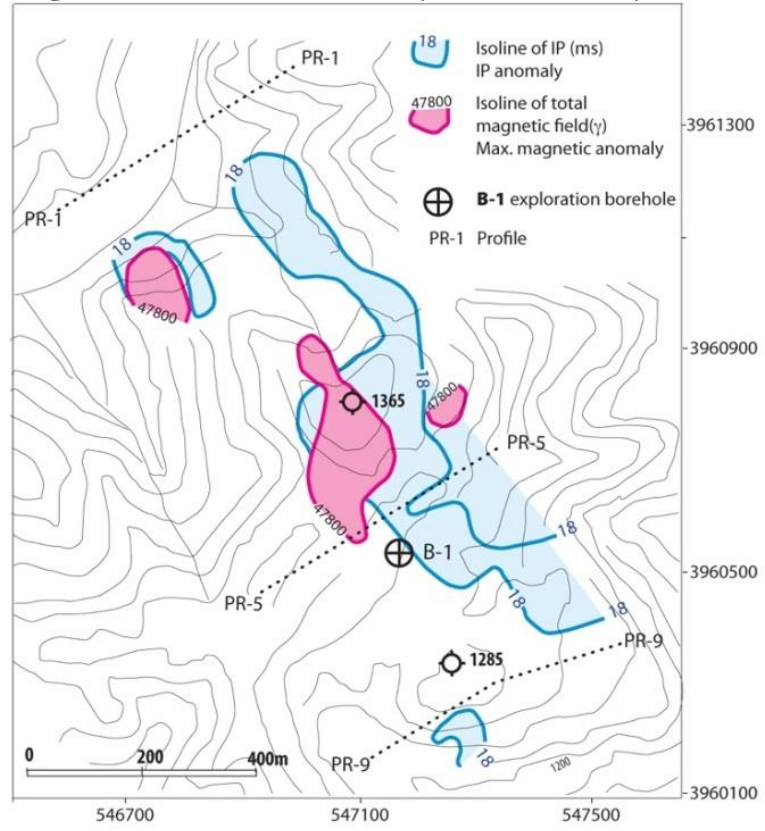

Larger magnetic anomaly in central part of the explored area corresponds with the zone of diabase rocks and secondary minerals - malachite, limonite etc.

\section{Mineralization}

The main host rocks of mineralization in Waraz area are pillow lava formation connected with basalt and basalt dykes and epidote veins, that showed IP measurement. Pillow lava lithofacies is highly tectonized, along the regional sheared zone. The potential area of ore mineralization has the area of about $3 \mathrm{~km}^{2}$. The mineralization host rocks are located at the very contact of the gabbro-diabase formation. Gabbro-diabase formation contains primary and secondary mineralization (Figure 14). Locally, pillow lava formation is thrusted over the gabbro-diabase formation or onto the Naopurdan mélange. 
Figure 14. Secondary Copper Mineralization Within Gabbro-Diabase Formation

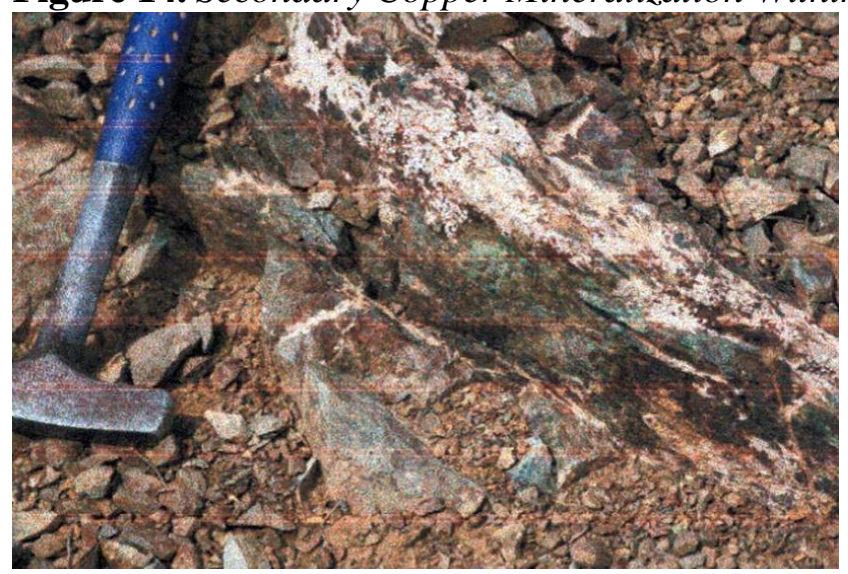

The zone can be recognised by limonitization of sulfides, and limonite staining on the rocks and numerous outcrops of secondary copper mineralization with malachites. The source of copper which occurrs in the pillow lava formation has a significent importance. It is recognized by widespread occurrence of secondary minerals (limonite, malachite, azurite) and primary sulfide minerals (chalcopyrite, pyrite, bornite). The gabbro-diabase formation is crosscut by numerous epidote and, in lasser extent, quartz veins. The intensity of mineralization correlates well with the intensity of epidotization. Massive limonite were formed stainings on the basalt after oxidation of massive vein sulfide-malachite (Figure 15).

Figure 15. Samples of Secondary Copper Minerals (Malachite)

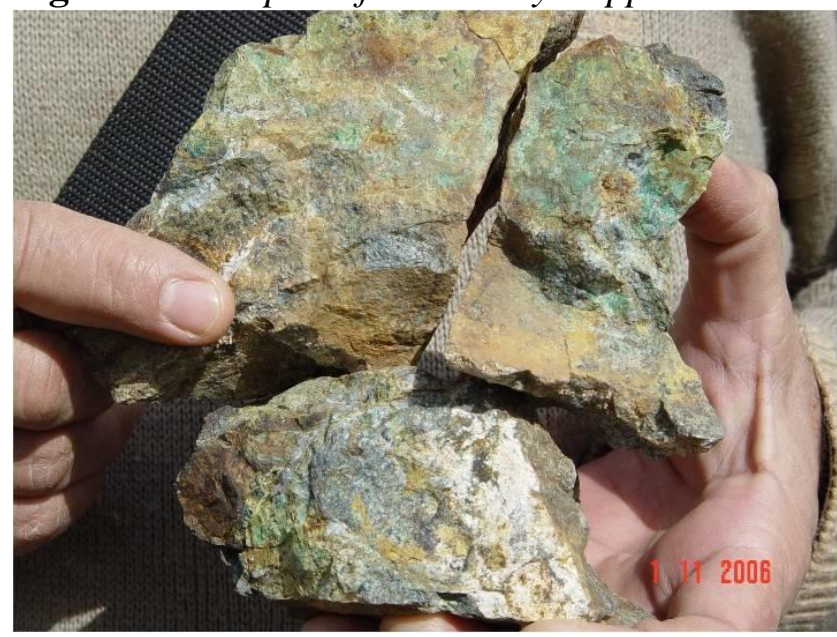

Geochemical analysis of representative rock samples taken in situ showed that the samples have increased $\mathrm{Cu}$ and some increased values of $\mathrm{Au}, \mathrm{Ti}$, and $\mathrm{Fe}$ (Table 1). The other elements $\mathrm{Cr}, \mathrm{Ni}, \mathrm{As}, \mathrm{Mo}, \mathrm{Ag}, \mathrm{Rb}, \mathrm{Bi}$, and $\mathrm{Zn}$ contain lesser concentracions. 
Table 1. Contents of $\mathrm{Au}, \mathrm{Ti}, \mathrm{Fe}$ and $\mathrm{Cu}$ in the Analysed Samples (10,000 ppm=1\% $\mathrm{Cu}$ ). (Eurotest Control, Sofia, 2007)

\begin{tabular}{|l|c|c|c|c|c|}
\hline $\mathbf{N r}$ & Sample No & Au (ppm) & Ti (ppm) & Fe (\%) & Cu (ppm) \\
\hline 1 & W-206 & $<0.05$ & 2,452 & 5.63 & 4,226 \\
\hline 2 & W-111 & $<0.05$ & 1,362 & 2.71 & 1.53 \\
\hline 3 & W-53 & $<0.27$ & 677 & 8.89 & 60,705 \\
\hline 4 & W-23 & $<0.05$ & 949 & 3.51 & 174 \\
\hline 5 & W-22 & $<0.05$ & 695 & 1.34 & 35 \\
\hline 6 & W-77 & $<0.05$ & 1,587 & 4.46 & 621 \\
\hline 7 & W-30 & $<0.05$ & 613 & 4.41 & 8,073 \\
\hline
\end{tabular}

The Rare Earth Elements (REE) were also analysed (16 elements), and (TR) 51 elements, but the concentration of the elements have not increased values.

\section{Konjirin-Kuradawi Area (B)}

This area is situated in central part of the Mawat ophiolitic complex, and covers the area of about $6 \mathrm{~km}^{2}$ (Figure 8). The area is primarily composed of the gabbro-diabase formation. Gabbro-diabase formation are cut by epidote and quartz veins, which contain limonite and malachite (Figure 16). The Konjirin area contains basaltoids of the pillow lava formation and a sheet dyke complex. At the contact with the mélange it obtained a wide range of textures from the pegmatitic gabbro, micro- and medium crystalline leucocratic and melanocratic gabbro, and at places achieved doleritic and diabase texture. The dominating types of the rocks in the study area are: diabase, gabbro, plagiogranite and epidotic veins.

Figure 16. Mineralization Zone of Gabbro-Diabase Rocks with Epidote and Quartz Veines

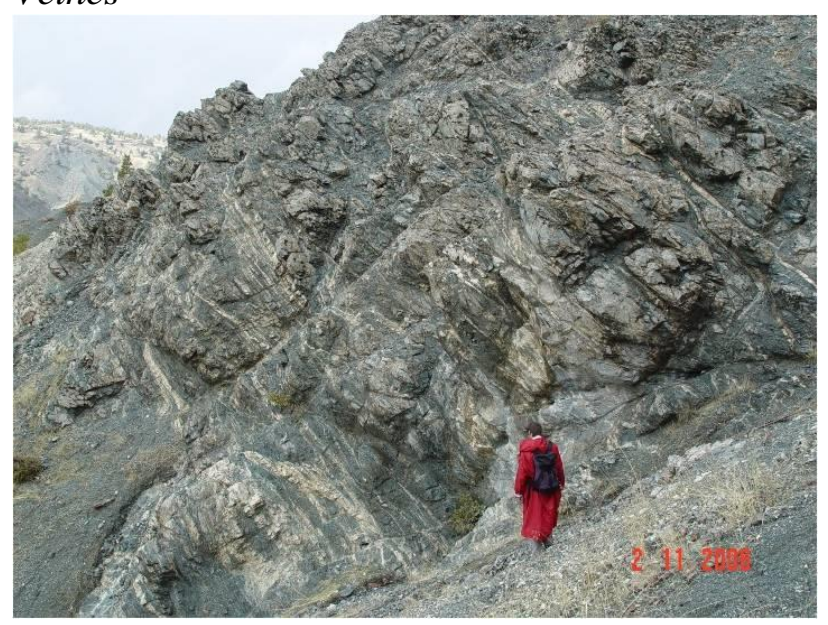

Tectonics in this area was very active and the rocks are very dissured and disarrangement. Specially stressed is the fault zone, NW-SE strike which is cut by numerous transverse faults (Figure 17). 
Figure 17. Rose Diagram of Ruptures in Konjirin Kuradawi Area

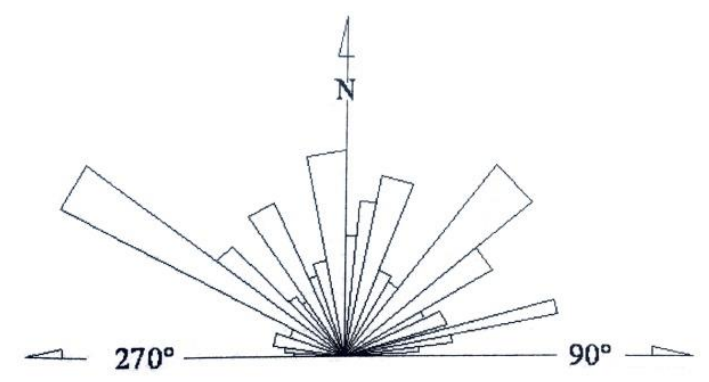

At the same time the localities with increased mineralization and limonatisation have been registered. In the diabase-gabbroid rocks were registered $\mathrm{Fe}-\mathrm{Cu}$ ore effusive cataclastite enriched with iron and copper minerals, which at the surface create limonite and malachite coatings. Flasered metadiabase (altered into greenshist metamorphic facies) have been determined by microscopic analyse (Figure 18).

Figure 18. Thin-Section of Flasered Metadiabase in Konjirin Area $\left(P 32 x . N^{+}\right)$

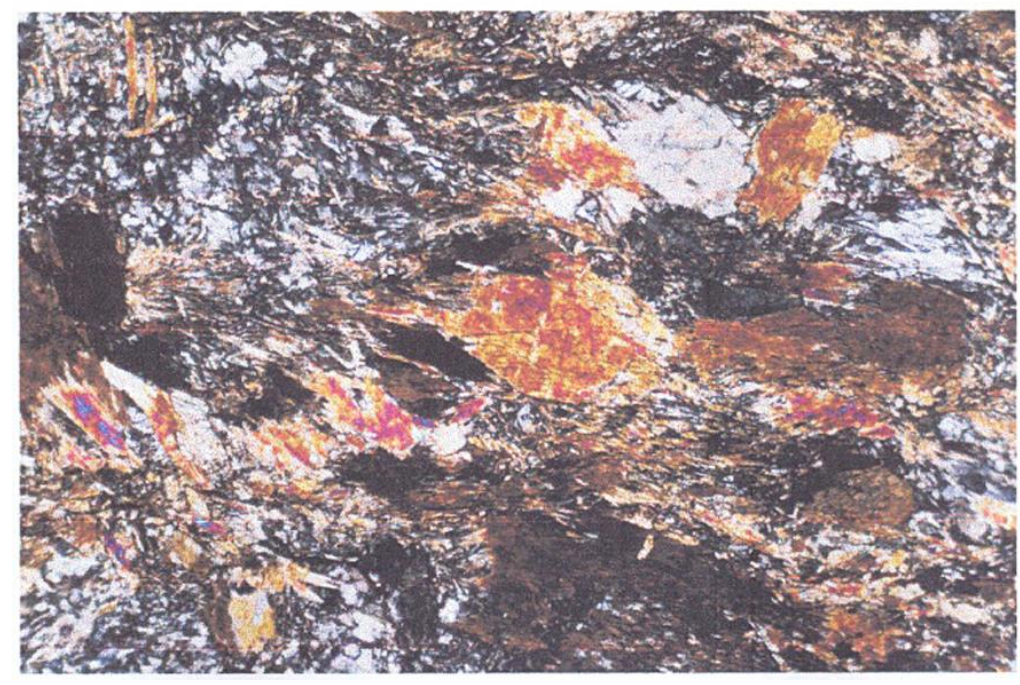

Geophysical survey

The map of induced polarization has values of $I P$ between $2 \mathrm{msec}$ and 34 msec. Zones with higher values of $I P$, with higher sulfide mineralization, are determined only on geoelectric profile measured in a creek, probably in a fault zone. On the map of apparent resistivity (ga) values of ga are in span between less then $600 \mathrm{Ohmm}$ up to more than $2,800 \mathrm{Ohmm}$. The zones of higher mineralization $I P$ are probably located on the contact of lower- and higher electrical resistivities and they are also coused by faults.

The map of self potential $S P$ shows values of $S P$ in range from $-32 \mathrm{mV}$ to over $+28 \mathrm{mV}$. The values of $S P$ also changed polarity on the contact zones.

The map of total magnetic intensity field $(\Delta T)$ shows values of $\Delta T$ in the span of $46,200 Y$ up to $49,800 Y$ Y. Higher values of total magnetic field $\Delta T$ are detected on the north and northwest parts of the exploration area, partly on the same place where induced polarization IP is also high. Based on measurement data, it could 
be concluded that anomaly zone IP of smaller dimension is situated on the intersection of larger dislocations with NE-SW and NW-SE strike. The zones of lower and higher resistivity generally corrrespond to existeing NW-SE dislocations.

\section{Mineralization}

The mineralized zone generally stretches from SE to NW, and is the best develloped in central part of the terrain. The main bearer of the mineralization are pillow lavas, connected with basaltic rocks and basaltic dykes, as well as with well developed epidote-quartz, closely associated with leucocratic rocks, supposingly plagiogranite. A wide zone of alteration has been recorded on the southern border of the Konjirin exploration area (Figure 19).

Figure 19. Alteration Zone with a Few Meters Thick Mineralization

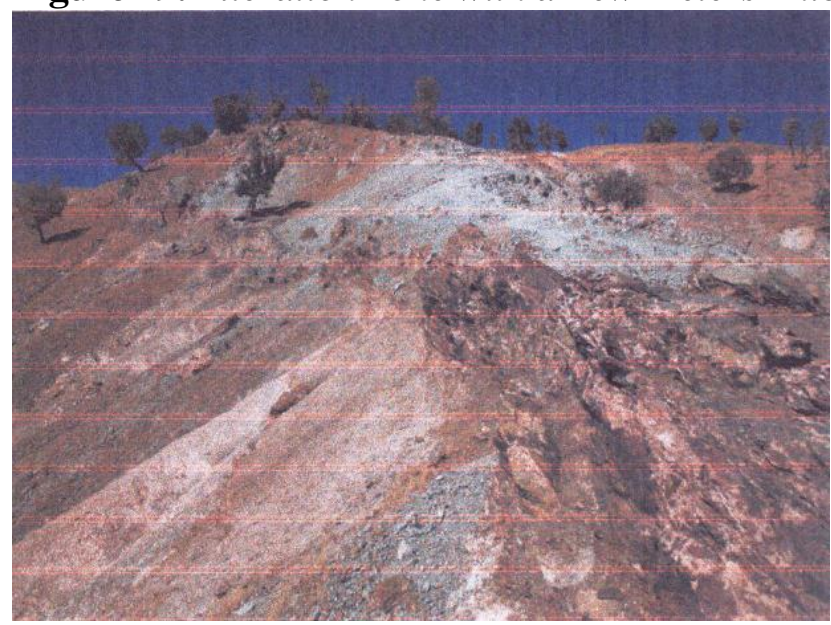

A fairly large number of geochemical analysis have been done, but here are presented only some of them (Table 2).

Table 2. The Contents of Some Analysed Sampels: $\mathrm{Au}, \mathrm{Ti}, \mathrm{Fe}, \mathrm{Cu}$ (Eurotest Control, Sofia, 2007)

\begin{tabular}{|l|c|c|c|c|c|}
\hline $\mathbf{N r}$ & Sample No & Au (ppm) & Ti (ppm) & $\mathbf{F e ~ ( \% ) ~}$ & $\mathbf{C u}$ (ppm) \\
\hline 1 & K-108 & 1.10 & 529 & 8.15 & 36.287 \\
\hline 2 & K-7A & 0.10 & 3,261 & 7.12 & 16.430 \\
\hline 3 & K-6A & 0.12 & 3,118 & 7.68 & 21.648 \\
\hline 4 & K-91 & $<0.05$ & 896 & 4.50 & 217 \\
\hline 5 & K-4A & 0.05 & 97 & 2.66 & 2,324 \\
\hline 6 & K-62 & $<0.05$ & 269 & 3.69 & 94 \\
\hline 7 & K-20 & $<0.05$ & 787 & 3.90 & 68 \\
\hline 8 & K-303D & 0.05 & 268 & 5.51 & 1,354 \\
\hline 9 & K-16 & $<0.05$ & 290 & 2.26 & 446 \\
\hline 10 & K-82D & 0.05 & 1,683 & 2.44 & 3,652 \\
\hline
\end{tabular}

It is obvious that the copper value have significantly increased $\mathrm{Cu}$ concentration in relation to others values. 


\section{Mirava - Chenaran Area (C)}

Mirava-Chenaran area is situated in northern part of the Waraz-Mawat ophiolitic complex, and covers about $9 \mathrm{~km}^{2}$ (Figure 8). Dominant rocks are gabbro with metagabbro, then basalts with metabasalts, metatuff/effusive and quartzmetaeffusives (Figure 20).

Figure 20. Thin-Section of Actinolite Shist with Iron Minerals (Actinolite, Acidie Plagioclase, Quartz-Epidote, Chlorite), the Rock is Rich with Magnetite and Pyrite $\left(P 32 x . N^{+}\right)$

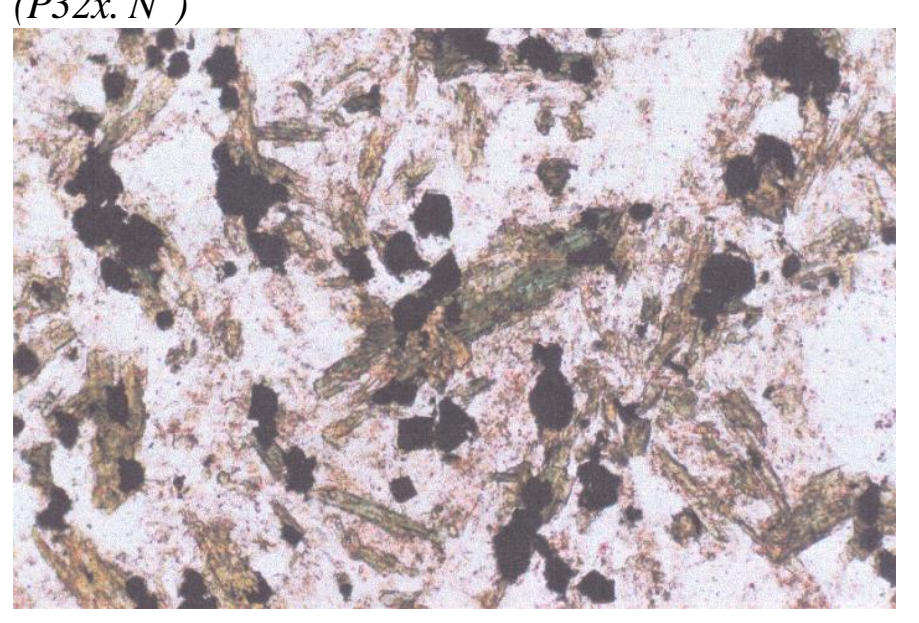

Diabase was found in central part of the area, and in places metadiabase is located more often along tectonic dislocations. Locally, plagiogranite was determined which can be gold bearer rocks. Epidote rocks are located in eastern and northwestern part of the area, more often connected to gabbro and diabase. These rocks often comprise increased mineralization especially of secondary minerals. Epidotic mineralized veins are connected to tectonic ruptures, and they are good indication of the mineralization. Tectonic activity in this area was very intensive, in particular radial tectonic, one can observe two general directions of faults: NW-SE, known as Zagros trend and NE-SW (Figure 21).

Figure 21. Rose Diagram of Ruptures in Mirava-Chenaran Area

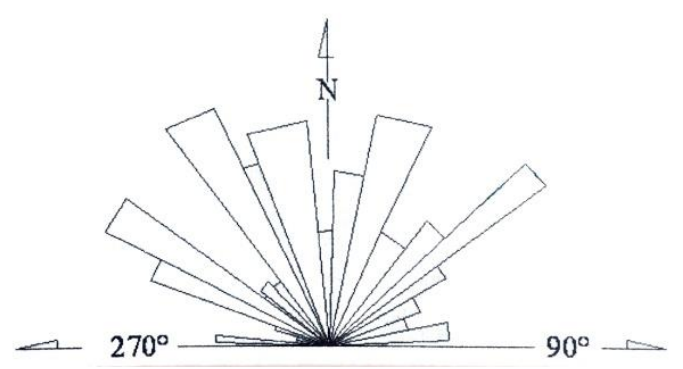

Geophysical survey

The same geophysical techniques have been used like in the studied areas A and B. Two IP smaller anomalies $(15-70 \mathrm{msec})$ were registered in the zones of 
increased electric resistivity ga which have been caused by gabbro and basalte rocks, that indicate increased sulfide mineralization Figure 22).

Figure 22. Induced Polarization (IP) Anomalies and ga Value of Lower and Higher Resistivity

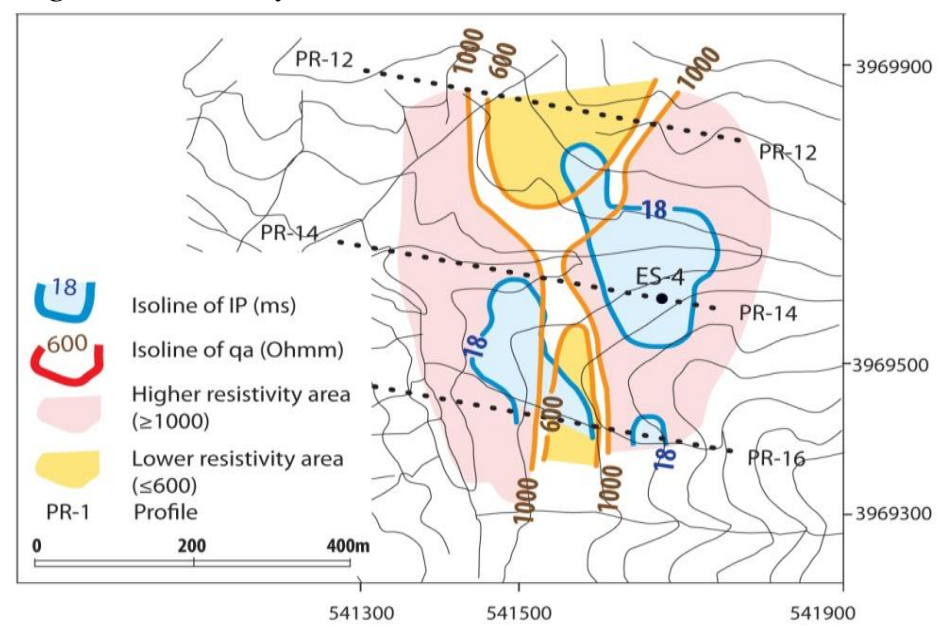

The zones of lower electric resistivity can be related to the occurence of epidote, and that coincide with tectonic dislocations of NW-SE strike.

\section{Mineralization}

The main bearer of mineralization in this area is pillow lava formation connected to basalts and basalt dykes. Mineralization is connected with well developed epidote-quartz, closely associated with leucocratic rocks, supposingly plagiogranite.

The outcrops with rich mineralization occur along the roadcut near the village of Mirava and Chenaran. It consists of highly limonitized gabbro and diabase dykes with occurences of secondary and primary copper mineralization (Figure 23).

Figure 23. Gabbro-Diabase Formation with Epidote-Quartz Veins and Copper Mineralization (Close to the Road to Mirava)

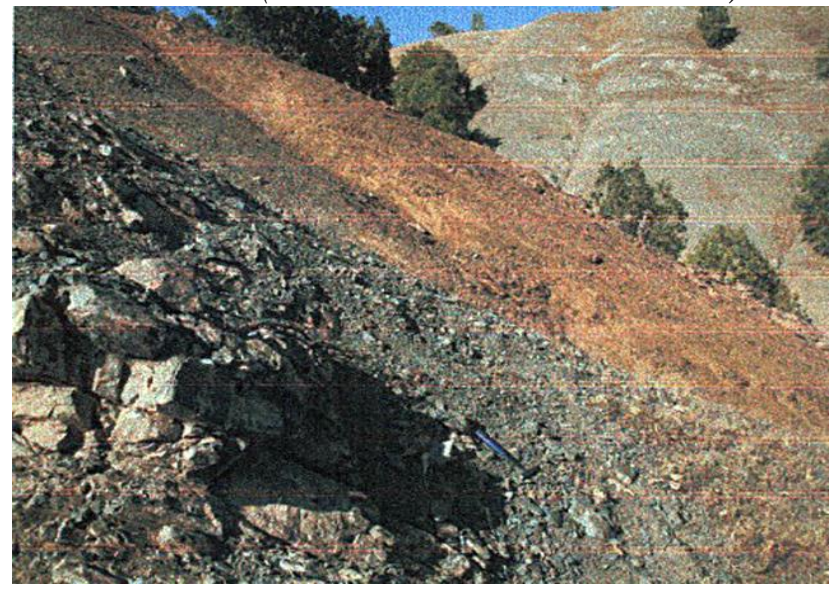


The rocks are intensely fractured and dissected by several generations of veins. The first system consists of epidote veins, ranging in size from several $\mathrm{cm}$ to $0.5 \mathrm{~m}$. The epidote veins are cut by quartz veins. Mineralization consists of secondary copper minerals, malachite and iron oxides. The whole rock unit was intruded by diabase dykes and sills, up to $1 \mathrm{~m}$ thick. Mineralization is closely related to the epidote-quartz veining (Figure 24).

Figure 24. Diabase Dykes Intruded and Tectonically Displaced in the Gabbro Rocks

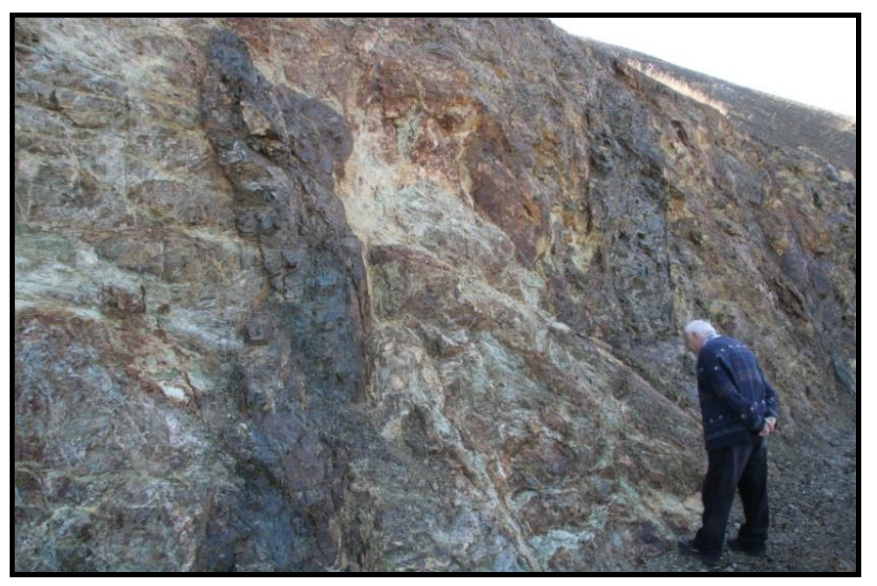

The Chenaran locality is characterised by a wide limonitizatin zone, which follows general strikes of the rock formations, mostly built of gabbro-diabase. Its intensity increases toward the Chenaran Village, where epidote-quartz ore veins are exposed, with malachite, limonite and primary sulfide minerals. The locality is mostly composed of gabbro-diabase rocks, which incorporate significante masses of plagiogranites (Figure 25).

Figure 25. Copper Mineralization: Primary Mineralization: Bornite, Chalcopyrite and Pyrite, and Secondari: Malachite and Limonite, (Near Chenaran Village)

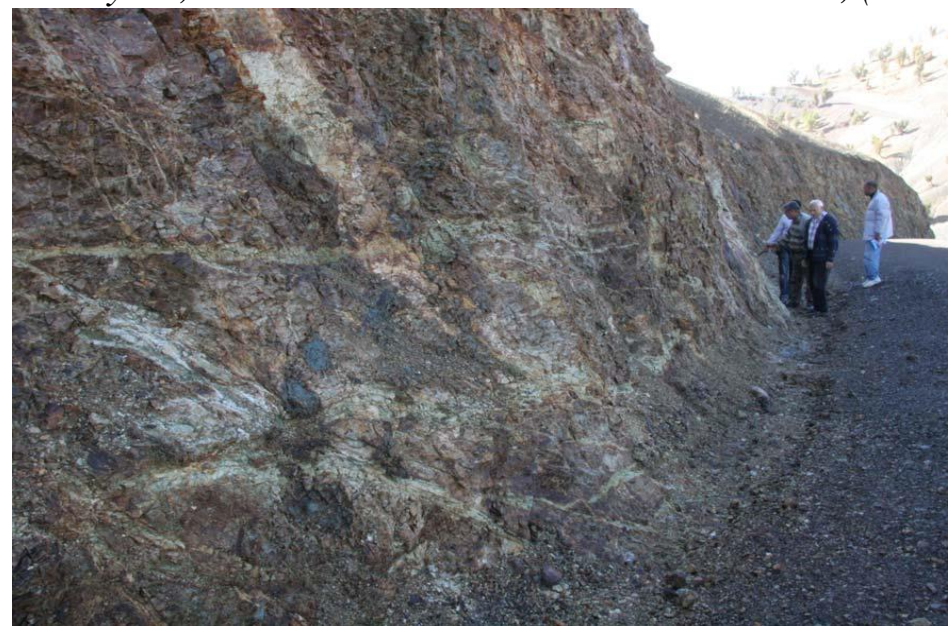


Primary mineralization zone it is evident in the Mirava village locality too, in gabbro-diabase formation, which incorporates significante masses of plagiogranites (Figure 26).

Figure 26. Mineralization Zone in Gabbro-Diabase with Plagiogranites in the Mirava Village Locality

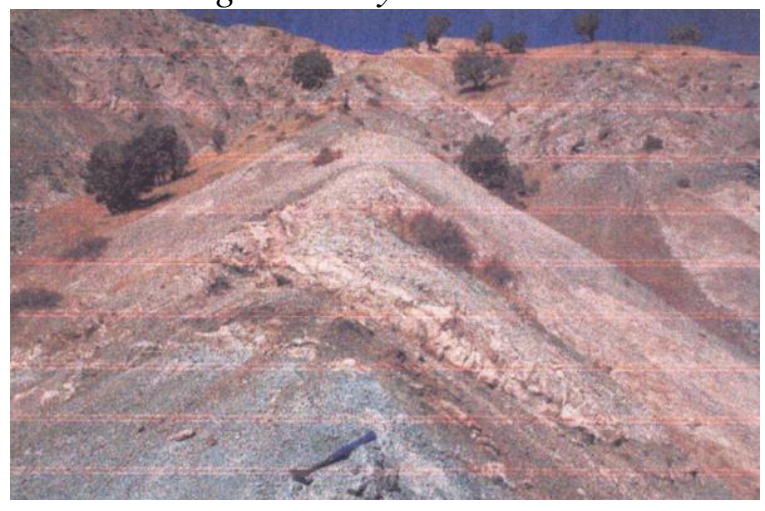

The Mirava locality is build of basalt-diabase formation with variable contribution of diabase, epidote-quartz veinis, gabbro pegmatites, and several zones of plagiogranites which are closely associated with mineralization. The mineralization is recognized in many outcrops in the area which extends from Mirava village to the contact with the Naopurdan formation. The plagiogranites contain $2.5 \mathrm{~g} / \mathrm{t}$ gold. The area of mineralization is very large, approximates $10 \mathrm{~km}^{2}$.

The clear signs of the primary mineralization are weathering products of sulfide: limonite, malachite, and chalcocite. Primary mineralization, consisting of bornite, chalcopyrite and pyrite (Figure 27) underwent replacement within the cementation zone, by chalcocite. The secondary mineralization is dominated by massive limonite and brown stainings of limonite (e.g., goetite) over the surfice surrounding host rocks. With decreased weathering, oxidizing zone turned sulfides into malachite and limonite, with rare relics of the chalcocite (Figure 28).

Figure 27. Copper Minerals: Chalcopyrite, Bornite, Pyrite and Malachite and Limonite in the Epidote-Quartz. Veins

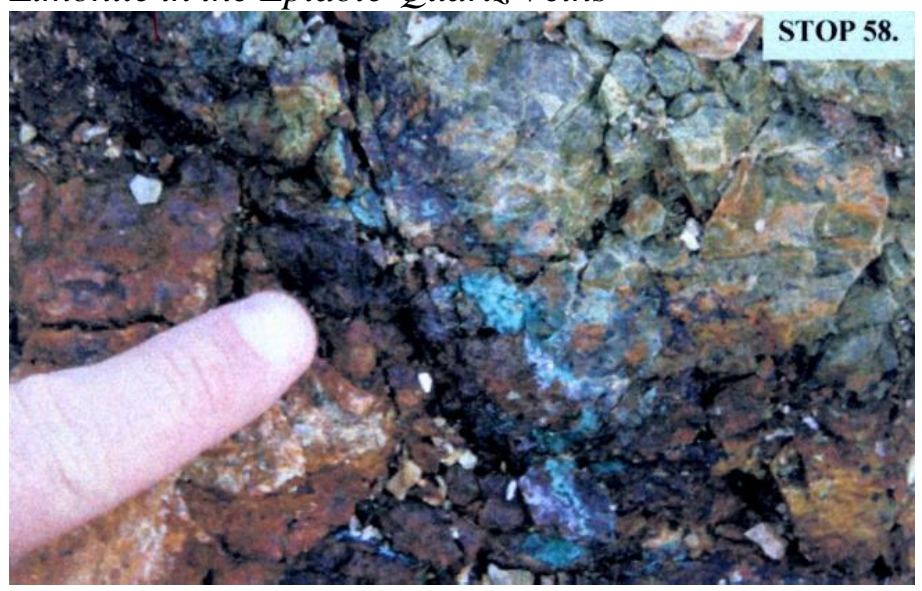


Figure 28. Copper Mineralization - Highly Weathered Rock, with Malachite and Limonite

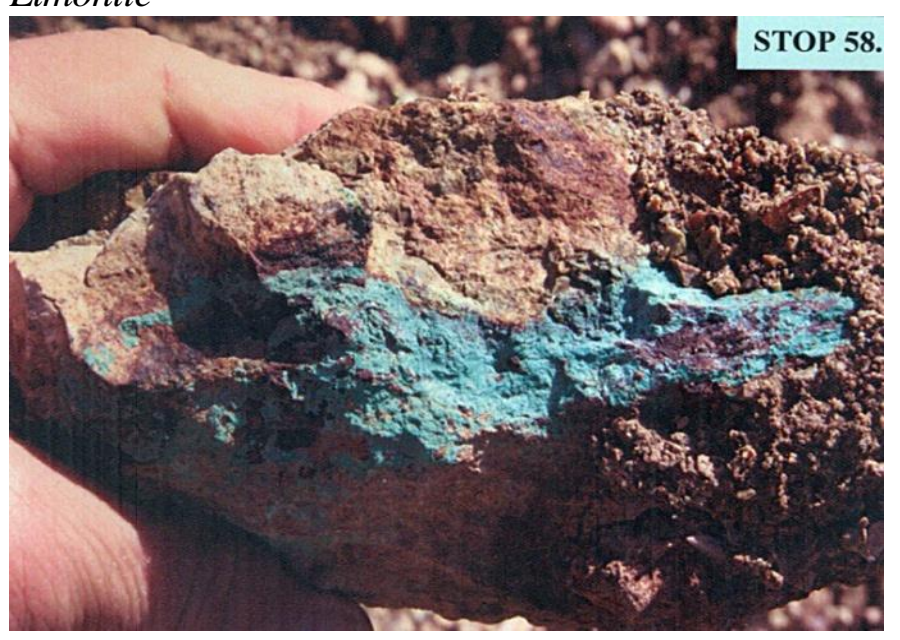

The mineralization zone can be followed generaly from SE to NW and is the best developed in the central part of the study area. The southeastern boundary of the mineralization is not constrained; a possible extension of the mineralization zone extends toward Waraz. Mineralization terminates on the north above the Kuradawi village too.

Geochemical analysis has been done on 17 elements and gold. The contents of gold in analysed samples is low $(<0.05-0.22 \mathrm{ppm})$ and the contents in other elements is insignificant. Here are presented only $\mathrm{Au}, \mathrm{Ti}, \mathrm{Fe}$, and $\mathrm{Cu}$ (Table 3).

Table 3. The Content of $\mathrm{Au}, \mathrm{Ti}, \mathrm{Fe}$ and $\mathrm{Cu}$ in the Analysed Samples (Eurotest Control, Sofia, 2007)

\begin{tabular}{|l|c|c|c|c|c|}
\hline $\mathbf{N r}$ & Sample No & Au (ppm) & Ti (ppm) & Fe (\%) & Cu (ppm) \\
\hline 1 & M-62 & $<0.05$ & 1,257 & 4.05 & 919 \\
\hline 2 & M-224 & $<0.05$ & 1,881 & 10.56 & 286 \\
\hline 3 & M-267 & $<0.05$ & 2,320 & 5.46 & 232 \\
\hline 4 & M-63 & $<0.05$ & 1037 & 6.86 & 135 \\
\hline 5 & M-217D & $<0.05$ & 2,065 & 3.17 & 478 \\
\hline 6 & M-246 & 0.22 & 1,428 & 3.89 & 5,875 \\
\hline 7 & M-204 & 0.05 & 993 & 6.26 & 16,803 \\
\hline 8 & M-266 & $<0.05$ & 2,948 & 2.71 & 4,378 \\
\hline
\end{tabular}

\section{Conclusions}

Geological exploration of copper mineralization was in the area of Mawat ophiolitic massif. Satellite ASTER and QuickBird images were used together with field prospection and geophysical survey, as well as petrographic and chemical analyses. The explored terrain is mostly composed of ultrabasic and basic rocks (peridotite, gabbros, serpentites, basalts, etc.). The rocks are intensely tectonised and intruded by numerous basic magmatic bodies. The host rocks of the mineralization are primarily gabbros and metagabbros intersected by diabase 
dykes, epidotic and quartz veins, covered by pillow lava formations. Copper mineralization is usually stained with limonite crust which is a good indicator of mineralization. Primary mineralization is represented by chalcopyrite, bournite and pyrite, while secondary mineralization malachite and limonite is a product of weathering.

In the study area, three smaller perspective areas were selected: Waraz, Konjirin-Kuradawi and Mirava-Chenaraan, which have copper mineralization. The registered concentration of copper varies highly, in wide range. The concentrations of $\mathrm{Cu}$ in samples are: Waraz area 1.53-60,705, Konjirin-Kuradawi 68-36,287 and Mirava-Chenaran 135-16,803 ppm. Maximum value of $\mathrm{Cu}$ was determined in the Waraz area $6.7 \% \mathrm{Cu}$. In some rock samples gold concentration of 0.36 and $2.59 \mathrm{ppm}$ were also determined.

Based on the collected information, the possible perspective of the mineralization bearing rocks has been roughly estimated. Farther action in selected localities detailed explorations as well as drilling is recommendable in order to precisely define economic properties of this area.

\section{Acknowledgments}

Authors are very grateful to ECOINA Co, Zagreb, Croatia which supported this exploration. We also thank our colleague geologists: P. Buva, D. Milovanović, L. Palinkaš, and geophysicists: V. Samolov, M. Pandurov and M. Divljaković who worked with us in field exploration. Our sincere thanks goes to the Kurdish colleagues who assisted in this exploration. We also thank our colleague D. Koželj for his useful consultation. Our acknowledge get also to the Eurotest-Contral PLC Laboratory, Sofia- Bulgaria for ore elements and gold analysis, as well as to Croatian Geological Survey for micropetrographic analysis of samples.

\section{References}

Al-Bassam KS (2013) Mineral resources of Kurdistan Region, Iraq. Iraqi Bulletin of Geology and Mining 9(3): 102-127.

Al-Hashimi RA, Al-Mehaidi MH (1975) Cu, Cr dispersion in Mawat ophiolite complex, NE Iraq. Journal of the Geological Society of Iraq (special issue): 37-47.

Al-Hilali HAM et al. (1991) Geological prospecting for copper mineralization in Waraz locality, Mawat igneous complex. Baghdad, Iraq: Ministry of Industry and Minerals State Establishment of Geological Survey and Mining-Directorate of Geological Survey.

Al-Mehaidi (1974) Simplified geological map of Mawat Ophiolites Complex NE Iraq. Journal of the Geological Society of Iraq (special issue): 37-44.

Azizi H, Hadi A, Asahara Y, Mohammad YO (2013) Geochemistry and geodynamics of the Mawat mafic complex in the Zagros Suture zone, northeast Iraq. European Journal of Geosciences 5(4): 523-537.

Bolton CMG (1955) Report on the geology and economic prospects of Qaladiza area site invest. Co. Ltd. Report no. 32. Baghdad, Iraq: D.G. Geological Survey and Mineral Investigation Library. 
Hamasalh RF (1982) Petrochemistry, petrogenesis and tectonic setting of the Pauza ultramafic rocks-bulfat complex North-East Iraq, Kurdistan Region. Master Thesis. Mosul, Iraq: University of Mosul.

Hassan MM, Brian G, Jones BG, Buckman S, Jubory IA, Ismail SA (2015) Source area and tectonic provenance of Paleocene-Eocene red bed clastics from the Kurdistan area NE Iraq: bulk-rock geochemistry constraints. Journal of African Earth Sciences 109(Sep): 68-86.

Ismail A, Sarmad A, Nutman AP, Bennet VC, Jones BG (2017) The Pushtashan juvenile suprasubduction zone assemblage of Kurdistan (northeastern Iraq): a Cretaceous (Cenomanian) NeoTethys missing link. Geoscience Frontiers 8(5): 1073-1087.

Jassim SZ (1975) Geology of the central sector of the Mawat igneous rocks, Northeastern Iraq. Journal of the Geological Society of Iraq 6: 83-92.

Moghadam HS, Stern RJ (2011) Geodynamic evolution of Upper Cretaceous Zagros ophiolites: formation of oceanic lithosphere above a nascent subduction zone. Geological Magazine 148(5-6): 762-801.

Oluić M, Palinkaš L, Milovanović D, Vasiljević R, Buva P (2007) Report on mineral exploration in Mawat Ophiolitic Massif, Kurdistan - Iraq (first exploration phase). Zagreb, Croatia: ECOINA. (Unpublished)

Oluić M, Milovanović D, Palinkaš L, Vasiljević R, Buva P, Romandić S, et al. (2008) Report on mineral exploration in Mawat Ophiolitic Massif, Kurdistan - Iraq (second exploration phase). Zagreb, Croatia: ECOINA. (Unpublished)

Othman AA, Gloaguen R (2014) Improving lithological mapping by SVM classification of spectral and morphological features: the discovery of a new chromite body in the Mawat ophiolite complex (Kurdistan, NE Iraq). Remote Sensing 6(8): 6867-6896.

Power GL (1954) Iraq mineral survey project, volume 3, six monthly report. GSM Lib. No. 264.

Smirnov VA, Nelidov VP (1962) Report on 1/200,000, prospecting correlation of the Sulaymanya-Choarta-penjwin area carried out in 1961. GSM Lib. No. 290.

Yara IOM, Mohammad YO (2018) Iron-copper mineralization associated with metagabbro in Mirawa Village, Kurdistan region, northeastern Iraq. Journal of Zankoy Sulaimani $20-2$ (Part-A).

Yara IOM (2019a) Copper mineralization in selected areas of Kurdistan Region, Iraq: a review on mineralogy and geochemistry. Iraqi Bulletin of Geology and Mining (special issue 8): 41-63.

Yara IOM (2019b) Mineralogy and stable sulfur isotopes of the sulfide mineralization in the Kuradawe Area, Mawat Ophiolite, Kurdistan Region, Northeastern Iraq. Iraqi Bulletin of Geology and Mining 16(1): 63-77.

Yassin T, Alabidi AJ,Hussain ML, Al-Ansari N, Knutsson S (2015) Copper ores in Mawat ophiolite complex (Part of ZSZ) NE Iraq. Natural Resources 6(10): 514-526. 
